\title{
Outcome of Peritoneal Dialysis in Children : Experience in a Tertiary Level Hospital in Chittagong, Bangladesh
}

\author{
Kamal Hossain ${ }^{1^{*}}$ \\ Md.Badruddoza \\ AMM Ehteshamul Hoque ${ }^{2}$ \\ 'Department of Pediatrics \\ Chattagram Maa-O-Shishu Hospital Medical College \\ Chittagong, Bangladesh. \\ ${ }^{2}$ Department of Nephrology \\ Chattagram Maa-O-Shishu Hospital Medical College \\ Chittagong, Bangladesh.
}

\begin{abstract}
Objective: The objective of the study is to see the outcome of peritoneal dialysis in child age group ranging from 6 months to 15 yearsadmitted in ChattagramMaaShishu-O-General Hospital ICU setup. Methods: Patients were selected randomly who admitted with the indication of renal replacement therapy.Intermittent peritoneal dialysis was done in 10 patients from February 2012 to January 2013. Results: Out of ten patients eight survived and two died due to complication.The success rate is $80 \%$.Among the survivors four made complete recovery with no complication and another fourwere sent to paediatric surgery for treatment of obstructive uropathy, the primary cause of the renal failure. Conclusion: The data presented indicate that peritoneal dialysis is an effective type of dialysis, that it is safe, that it can be accomplished with a minimum of equipment and that a trained team is essential for its efficient use. It is the preferable practical procedure currently available by which dialysis of an anuric infant or small child can be accomplished.
\end{abstract}

Key words: Peritoneal dialysis; Children; PD catheter; Hypernatremia; Obstructive uropathy; Hemolytic uremic syndrome; Septicemia; Renal failure.

\section{INTRODUCTION}

Worldwide, peritoneal dialysis (PD) has long been recognized as the dialysis modality of choice for pediatric renal failure patients. Not only is the treatment regimen flexible to a variety of family lifestyles and environments; placement of a PD access is usually possible throughout early developmental stages of the lifespan. With infants, hemodialysis (HD), although technically possible, is difficult. Maintenance of a functional and complication-free vascular access can be problematic. The decision to select PD as a dialysis modality for the pediatric patient requires considering several factors including patient size, medical co-morbidities, and overall family support ${ }^{1,2,4}$. We lost many patients before, due to lack of peritoneal dialysis facilities in Chittagong. Now we were able to establish a fullfledged Paediatric-Nephrology \& Peritoneal Dialysis unit in Chattagram MaaShishu-O-General Hospital.

\section{MATERIALS AND METHODS}

The study period was from February 2012 to January 2013.In this period IPD(Intermittent Peritoneal Dialysis) done in 10 patients for different indications such as Acute watery diarrhea with hypernatremic dehydration with acute renal failure,Hemolytic uremic syndrome and CRF due to obstructive uropathy.Peritoneal dialysis was done by a trained team in ChattagramMaa-Shishu-O-General Hospital Paediatric ICU setup.

In this study we used disposable Medical Tenckhoff PD catheter ${ }^{2,10}$. Site for insertion of catheter in all cases was two-third of the distance from the umbilicus to the left last rib just lateral tothe border of rectusabdomenis muscle ${ }^{10,12}$.

The bladder was emptied before catheter insertion. The procedure was done under aseptic technique. Then, the set of PD lines was prepared and the patency of fluid channel was checked. The area was cleaned withpovidone iodine and the patient was draped. Then, the area was infiltrated with lignocaine for local anaesthesia.

\section{Dr. Kamal Hossain}

Registrar

Department of Pediatrics

Chattagram Maa-O-Shishu Hospital Medical College Chittagong, Bangladesh.

Mobile: +880-1912501800

E-mail : drkhjewel@yahoo.com 
For young childrenadditional I/V sedation were needed. For very small infants and patients with very scaphoid abdomen, one may needto infiltrate the abdominal cavity using a canula size 20G or larger with $10-15 \mathrm{ml} / \mathrm{kg}$ PD fluids before catheter insertion to prevent traumatic puncture ofunderlying viscus. A small skin incision, slightly smaller than the diameter of the catheter is madeusing a sharp pointed blade. The muscle layer is not cut. The catheter was checked carefully by withdrawing the stilette from thecatheter for any breakages before insertion. The catheter with the stilette was introduced perpendicular to the abdominal wallwhile controlling the length with the dominant hand until the peritoneum ispierced. The stilette was then withdrawn and the catheter gently pushed in,directing towards either iliac fossa.The catheter then connected to the PD lines. Skin sutures were not necessary where a retaining knob was present. Bleeding from theinsertion site wasstopped by a pursestring suture. Dressingwas done with dry gauze orgauze impregnated with povidine iodine for the older children ${ }^{8-15}$.

We started at $20 \mathrm{ml} / \mathrm{kg}$ and observed for discomfort, cardiorespiratory changes orleakage at the catheter site.The volume was increased by $5 \mathrm{ml} / \mathrm{kg} / \mathrm{run}$ up to a maximum of $40 \mathrm{ml} / \mathrm{kg}$ in infants ${ }^{12}$. First 6 cycles were rapid cycles i.e. no dwell time.Subsequent cycles usually lasted an hour 5-10 minutes to instill (depending on exchange volume), 40 minutes dwell, 10-15 minutes to drain (depending on exchange volume). As homeostasis improves, longer dwelling was instituted. The cycles were done manually ${ }^{1,10,12,13}$.

Table 1: Patient particulars and outcomes
In our cases commercially available dialysis fluid $1.5 \%$ dextrose were used. PD was usually initiated with $1.5 \%$ and watched for hyperglycaemia.As no hyperglycemia occurs, so we didn't go for higher concentration of dialysis fluid. We added $3 \mathrm{ml}$ of potassium chloride [1 g $(13 \mathrm{mmol})$ in $10 \mathrm{mls}$ ] in everylitre dialysate if serum $\mathrm{K}^{+}$was found $<4 \mathrm{mmol} / \mathrm{l}$. The addition of heparin (500 units/litre dialysate) was used for thefirst 3 days and subsequently if blood or fibrin was present in the effluent.We didn't use bicarbonate as lactic acidosis was not a problem in our cases ${ }^{12,13,15}$.

The duration of PD depends on the needs of the patient, we used 60 cycles of PD usually but at times more cycles were needed basedon biochemical markers or clinical needs. Serial measurements of fluid balance, weight, vital signs and serum chemistries anddialysate effluent for daily cell count and culture were done. The study was duly permitted by the hospital authority and proper consent was taken from the parents.

\section{RESULTS}

During last one year period we did peritoneal dialysis in 10 patients. Out of those, 5 patients were suffering from diarrhea with hypernetremia $(50 \%), 4$ patients were CRF due to obstructive uropathy (40\%) and 1 was HUS (10\%). Total two patients died (20\%); one died 6 hours of IPD due to Severe metabolic acidosis and another patient died 2 days after IPD due to septicemia. Our success rate is $80 \%$. A mong recovery, four patients referred to pediatric-surgery for correction of obstructive uropathy. The results are mentioned in table-1.

\begin{tabular}{|c|c|c|c|c|c|c|}
\hline Caseno & Age & Initial parameters & Diagnosis & \multicolumn{2}{|c|}{ Duration of PD } & Complication Comments \\
\hline Case-1 & 18 months & $\begin{array}{l}\text { S.Na+ } 194.6 \mathrm{mmol} / \mathrm{l} \\
\text { pH } 7.24 \\
\text { S.creatinine } 1.2 \mathrm{mg} / \mathrm{dl}\end{array}$ & $\begin{array}{l}\text { AWD with hypernatremic } \\
\text { dehydration with ARF }\end{array}$ & 72 hours & None & Survived \\
\hline Case-2 & 11 months & $\begin{array}{l}\text { S.Na }+198 \mathrm{mmol} / \mathrm{l} \\
\mathrm{pH}<6.9 \\
\text { S.cr } 2.6 \mathrm{mg} / \mathrm{dl}\end{array}$ & $\begin{array}{l}\text { AWD with hypernatremic } \\
\text { dehydration with ARF with } \\
\text { M etabolic acidosis }\end{array}$ & 6 hours & & $\begin{array}{l}\text { Died during PD due } \\
\text { to severe metabolic } \\
\text { acidosis }\end{array}$ \\
\hline Case-3 & 15 years & $\begin{array}{l}\text { S.cr } 8.6 \mathrm{mg} / \mathrm{dl} \\
\mathrm{pH} 7.15\end{array}$ & $\begin{array}{l}\text { CRF due to } \\
\text { Obstructive uropathy }\end{array}$ & 72 hours & None & Improved \\
\hline Case-4 & 8 years & $\begin{array}{l}\text { S.cr } 6 \mathrm{mg} / \mathrm{dl} \\
\mathrm{pH} 7.2\end{array}$ & $\begin{array}{l}\text { CRF with bilateral gross } \\
\text { hydronephrosis with bladder } \\
\text { diverticula with metabolic acidosis }\end{array}$ & 72 hours & None & Improved \\
\hline Case-5 & 8 years & $\begin{array}{l}\text { S.cr } 5.6 \mathrm{mg} / \mathrm{dl} \\
\mathrm{pH} 7.25\end{array}$ & CRF with obstructive uropathy & 72 hours & None & Improved \\
\hline Case-6 & 18 months & $\begin{array}{l}\text { S.Na }{ }^{+} 187 \mathrm{mmol} / \mathrm{l} \\
\mathrm{pH} 7.35 \mathrm{~S} . \mathrm{cr} 1.8 \mathrm{mg} / \mathrm{dl}\end{array}$ & $\begin{array}{l}\text { AWD with hypernatremic } \\
\text { dehydration with ARF }\end{array}$ & 72 hours & $\begin{array}{l}\text { Peritonitis developed, } \\
\text { E.coli growth in PD fluid }\end{array}$ & Survived, normal \\
\hline Case-7 & 15 months & $\begin{array}{l}\text { Hb } 5.9 \mathrm{~g} / \mathrm{dl} \text {,Platelate } \\
-80,000 / \mathrm{cmm}, \mathrm{RBC} \text { in } \\
\text { urine,S.cr } 8 \mathrm{mg} / \mathrm{dl} \text {, } \\
\text { PBF-haemolytic anemia } \\
\text { with fragmented RBC }\end{array}$ & $\begin{array}{l}\text { HUS(haemolytic uremic } \\
\text { syndrome) }\end{array}$ & 72 hours & $\begin{array}{l}\text { Peritonitis developed, } \\
\text { pseudomonas growth } \\
\text { in PD fluid }\end{array}$ & Survived, normal \\
\hline Case- 8 & $7 \mathrm{yrs}$ & $\begin{array}{l}\text { S.cr } 5.8 \mathrm{mg} / \mathrm{dl}, \\
\mathrm{pH} 7.15\end{array}$ & $\begin{array}{l}\text { CRF with } \\
\text { M etabolic acidosis }\end{array}$ & 72 hours & None & Improved \\
\hline Case-9 & 8 months & $\begin{array}{l}\text { S. } \mathrm{Na}^{+} 176 \mathrm{mmol} / \mathrm{l} \\
\text { S.cr } 1.2 \mathrm{mg} / \mathrm{dl}, \\
\text { pH } 7.2, \mathrm{HCO3}^{-} 14 \mathrm{mmol} / \mathrm{l}\end{array}$ & $\begin{array}{l}\text { AWD with hypernatremia } \\
\text { with ARF with } \\
\text { M etabolic acidosis }\end{array}$ & 72 hours & $\begin{array}{l}\text { Peritonitis } \\
\text { developed, K lebsiella } \\
\text { growth in PD fluid }\end{array}$ & Survived, normal \\
\hline Case-10 & 12 months & $\begin{array}{l}\mathrm{S.Na}+173 \mathrm{mmol} / \mathrm{l} \\
\mathrm{S} . \mathrm{cr} 2.6 \mathrm{mg} / \mathrm{dl} \text {, } \\
\mathrm{pH}<6.90, \mathrm{HCO} 3-6.0 \mathrm{mmol} / \mathrm{l}\end{array}$ & $\begin{array}{l}\text { AWD with hypernatremia } \\
\text { with ARF with M etabolic } \\
\text { acidosis }\end{array}$ & 72 hours & $\begin{array}{l}\text { Peritonitis } \\
\text { developed, E.Coli } \\
\text { growth in PD fluid }\end{array}$ & $\begin{array}{l}\text { Died } 2 \text { days after } \\
\text { IPD stoped due } \\
\text { to Septicemia }\end{array}$ \\
\hline
\end{tabular}




\section{DISCUSSION}

Pediatric PD evolved on the heels of the therapy's early investigative work within the adult ESRD population. Reports published by Bloxsum and Powell in 1948 and Swan and Gordon in 1949, describe PD as a treatment option for children with acute renal failure $(A R F)^{1,2,3,4}$. Undeterred by embryonic PD technologies, Swan and Gordon employed available resources such as 60-watt light bulbs over the dialysate inflow path to regulate temperature of the dextrose solution. Novel investigative work continued and in 1961, Seger and colleagues reported the success of pediatric PD for treatment of ARF. Though successful, treatments were plagued with the repeated insertion and removal of metal catheters ${ }^{1-4}$. In 1968, Tenckhoff and Schecter introduced a safe and permanent catheter which revived interest in PD. Shortly after this innovation, the development of an automated delivery system together with the availability of commercial dialysate revolutionized the ability to perform PD in the home setting. The novel concept of equilibration dialysis transformed PD into a popular, effective, and acceptable form of renal substitution therapy. Continuous ambulatory PD (CAPD) was born providing an appealing alternative to HD (Hemodialysis). Freedom from needle punctures, reduced dietary and fluid restrictions, and decreased risk of disequilibrium syndrome were recognized as potential benefits of choosing PD as one's dialysis modality. The first reported use of CAPD in a child was in Toronto in $1978^{6,7,8,9,10,12}$. In Bangladesh Peritoneal Dialysis in Pediatric age group started several years ago in Dhaka, specially in BSM M U, subsequently in National Institute of K idney Disease and Dhaka Shishu Hospital. But in Chittagong we are pioneer in starting Peritoneal Dialysis from 1st February 2012 in ChattagramM aa-Shishu $O$ G eneral Hospital.

PD dialysis fluid is made up of a glucose solution, different concentrations of glucose are provided in order to hel $p$ with the removal of excess fluid in the blood. The fluid in the blood is pulled across the peritoneal membrane to 'dilute' the glucose using the process called osmosis. In order to increase the amount of fluid removed a higher concentration of glucose would be used. Waste products are removed from the blood through the process called diffusion; this process means that molecules will pass from the stronger solution (blood) into the weaker solution (dialysate) $)^{12-15}$.
Indications for PD are fluid overload as in Pulmonary edema, Congestive cardiac failure, Refractory hypertension, Hindrance to adequate nutrition,Oliguria following recent heart surgery, Oliguria during ECM O; Symptomatic electrolyte/acid-base imbalances as in Hyperkalaemia $(K+>7.0)$, Hypo- or hypernatraemia, A cidosis ( $\mathrm{pH}<7.2$ : or $<7.3$ withhyperkalaemia), toxins such as U reamia (puritus, pleuritis, pericarditis, CNS symptoms),Hyperuricemia, Exogenous toxins: lithium, salicylate, ethanol, methanol, bromide, ethylene glycol, aminoglycosides. Haemodiaysis (HD) is the therapy of choice for rapid treatment of dialyzable poisonings ${ }^{4,5,6,7}$ and Inborn errors of metabolism with encephalopathy and Hyperammonemia.In our series, 5 were hypernatremia, 4 were CRF due to obstructive uropathy and 1 was ARF due to Haemolytic-U reamic syndrome Contraindicationsof $P D$ are abdominal wall defects of infection, bowel distension, perforation, adhesion or resection andCommunication between the chest and abdominal cavities.

Common complications are Poor drainage (omental obstruction, kinking), Peritonitis,Exit site infection,L eaking dialysate at exit site and leakage from tubing. One of our patient developed peritonitis and another septicemia. Both the patient died out of complications.

\section{CONCLUSION}

In experienced hands peritoneal dialysisis a convenient, effective, and reasonably safe way of treating acute renal failure; it is best performedin centers capable of handling complex metabolic problems and investigating and treating theunderlying renal disease. In a developing country, the method can also be used to survivethe patientwiththis simple technical maneuver.

Competing Interest : The authors have no competing interest.

\section{ACKNOWLEDGEMENT}

The authors like to acknowledge the support provided by the doctors, nurses and other staffs of the Pediatric ICU ward of CMSGH.

\section{REFERENCES}

1. K aplan S A, Strauss J, and Yiiceoglu A M. Conservative management of acute renal failure. PEDIA mI c5, 25:409, 1960.

2. Segar W E. Peritoneal dialysis in the treatment of boric acid poisoning. New Engi. J. M ed. 282:798, 1960.

3. Schreiner C E, et al.Specific therapy for salicylism. N ew Engl. J. M ed. 253:213,1955.

4. Kyle L H, et al.The application of hemodialysis to the treatment of barbiturate intoxication. J. Clin. Invest. 32:364, 1953.

5. Merrill J P, and Weller J M. Treatment of bromism with the artificial kidney. A nn. Int. M ed. 37:186, 1952.

6. Danzig $L E$, and $K$ ringelA J. U se of the artificial kidney in treatment of thiocyanate psychosis. J.A.M .A.158:560, 1955

7. Carter $\mathrm{F} \mathrm{H}$,et al. Hemodialysis in children. J. Pediat. 51:125, 1957.

8. Kelemen W A, and Kolif W J. Use of artificial kidney in the very young, the very old, and the very sick. J.A.M .A. 171:530,1959.

9. Spritz N S, et at. The use of extraoorporeal hemodialysis in the treatment of salicylate intoxication in a 2-year old child. PzrnA mrcs,24:540, 1959.

10. Putnam T J. The living peritoneum as a dialyzing membrane. A mer. J. Physiol. 63:548, 1923.

11. Ganter C. U eberdieB eseitigunggiftigerStoffeausdemB lutedurchDialyse. M uenchen M ed. W schr. 70:1478, 1923.

12. Odel H. M, Ferris D 0, and Power M H. Peritoneal lavage as an effective means of extrarenal excretion. A mer. J. M ed. 9:63,1950.

13. M axwell M H, et al.Peritoneal dialysis: I.technique and applications. J.A.M .A. 170:917, 1959.

14. Doolan P D, et al.A n evaluation of intermittent peritoneal lavage. A mer. J. M ed. 26:831, 1959.

15. Grollman A, Turner $L B$, and $M C L$ ean J A. Intermittent peritoneal lavage in nephrectomized dogs and its application to the human being. A rch. mt. M ed. 87:379,1951.

16. Holiday M A, and Segar W E. The maintenance need for water in parenteral fluid therapy. PEDIA mI c5, 19:823, 1957. 